Journal of Awareness

Cilt / Volume 4, Sayı / Issue 3, 2019, pp. 409-418

E - ISSN: 2149-6544

URL: https://www.ratingacademy.com.tr/ojs/index.php/joa

DOİ: https://doi.org/10.26809/joa.4.032

Araştırma Makalesi / Research Article

\title{
A COMPARATIVE STUDY ON VIEW POINTS OF IMAM ALI AND CONFUCIUS ON EDUCATION
}

\section{Hojjatollah JAVANI * \& Marzyeh HEYDARI ** \& Noorisadat SHAHANGIAN ***}

\author{
* Alzahra University, IRAN, \\ E-mail: hojjatollahj@gmail.com \\ ** Alzahra University, IRAN, \\ E-mail: hojjatollahj@gmail.com \\ *** Alzahra University, IRAN, \\ E-mail: n.s.shahangian@alzahra.ac.ir
}

Geliş Tarihi: 5 Temmuz, 2019; Kabul Tarihi: 28 Temmuz 2019

Received: 5 July 2019; Accepted: 28 July 2019

\section{ABSTRACT}

Generally speaking the matter of education has been proposed during long history of human beings. As a matter of fact, Confucius as a great Chinese thinker and Imam Ali as a great Muslim Imam have paid to philosophy, values and ends of education. It would be interesting to discuss similarities and differences of these both distinguish thinkers in regard to Education. One might be wondered as he come to know that both of them emphasis on necessity and need of education for people. Although the end of education might differ among between them. Development and evolution of man's capacities and faculties, realizing justice, paying attention to morals and everlasting values, training men through proper methods and leading men towards good deeds are among their similarities.

Keywords: Confucius, Imam Ali, Education, Perfect Man, Values. 


\section{INTRODUCTION}

The main question of this essay deals with a comparative study on education from point of views of Confucius and Imam Ali. Would it be possible to find similarities among two great thinkers from different cultures and religions? Did both of them pay to the matter of men's ethical training and education? What were their principles, methods and goals in regard to education? By considering teachings and tenets of these think tankers of Chinese and Islamic cultures, one might come to some important results. It seems that both of them have paid to man's evolution, perfect man, and the concept of salvation. Both of them had much attention to the educational needs of man. They wanted to develop man's capacities as well. They proposed an ideal society and men. The both thinkers had their methods as to edition and training.

\section{LIFE OF CONFUCIUS}

Confucius or Kong Fu - Tzu was born in a poor family in 551 B.C in Lu provenience. Some miracles have been narrated as to his birth which they are not any proved as well. He lost his father when he was a baby. He says that: I was a child of a poor man so I paid to cheap works which was not suitable for prince and loyal families (Confucius 1955: 61). He learned Chinese wisdom, teachings, history, accounting, music, cults and sports. He was China's most famous teacher whose ideas have influenced the civilization of all eastern Asia. Confucius was deeply influenced of the crisis of his society. He reached to official and judiciary positions for a very short period but he left official positions soon. He had less impact on people in his life but became famous and influential after his death. It might be said that he was unable to implement his ideas of reform; he spent the greater part of his life for educating a small group of disciples. He was not a religious leader in the ordinary sense, for his teaching was essentially a social ethics Some researches hold that he had a long and permanent influence not only on Chinese cultures but also on Western thinkers too, that is to say on thinkers of Enlightenment period. His disciples developed his ideas and made him a founder of socio-philosophical school. Mencius was one of his famous students. Chu She was a famous interpreter of Confucius and he had much influence on modern Chinese thought (Walshe 1981: 18) wrote many books which are famous now. It seems that he was much impressed by historical and literary heritage of ancient china but he had a creative approach towards this heritage. He died in 470 BC.

\section{LIFE OF IMAM ALI}

Ali Ibn Abi Talib born in Mecca in 600. He belonged to Hashemite family, a famous one in Mecca. He was cousin of the prophet of Islam and became his son in law later (Qomi 1426AH:141). He became Muslim very soon and then endeavored much to develop and spread it. He was constantly with Prophet of Islam and participated in all wars (Shahidi 1384AH:30). He became the fourth Caliph of prophet of Islam. He is the first Imam of Shia as well.He became forth Caliph of Muslims and rulled from 36 up to $40 \mathrm{AH}$ (Modarresi 1380AH : 76), He is so much famous in regard to efforts for realizing justice during his rule as forth Caliph of the prophet of Islam. He martyred in 40 of Islamic Calendar by one of his opponent .He lived 63 years (Tabresi 1398AH: 230). He presented many lectures, religious sermons and preaches. His preaches contain many teachings on God, man and universe. He had his especial approach towards man's education and ethical behavior. Main sources of his thought are Quran and the tradition of the holy prophet (Hosaini Sardari 1364:30).

\subsection{CONFUCIUS AND IMAM ALI ON METAPHYSICS.}

Generally speaking the matter of metaphysic has been one of the main questions of human kind. Confucius was mainly a social thinker so he did not concentrate on metaphysics. (Creel 1380AH:57).But he devoted much of his time in the way of social philosophy. That is to say, his main concern was as to society and destiny and welfare of men. It is to be mentioned 
that he was primarily a teacher of ethics (Noss 1965: 392). In private belief and public practice he exhibited faith in religious reality .But he hold that absorption in the study of the supernatural is most harmful (Ibid, idem) .Confucius mainly proposed matters as to how one might live in society. So he had less motivation to step towards unsolved philosophical questions (Jaspers 1393AH: 262). He usually thought as to social reform and his main concern was to live according to truth. He wanted to create a rightful society. He made much attention to social reforms. One must not judge on ideas of Confucius only according to his main social concerns. He holds that one need to make his worldly life based on ethical values. So discussions on metaphysics were considered as secondary topics not primary one to him.

Confucius world view regarding the universe was based on the concept of Tao as a universal element. Tao means way or road. Confucius considers Tao as "Way of act" (Creel 1949: 67). It is a way superior to other ways. He holds that each Phenomena in the nature has two aspects. I.e. Yang and Yin or positive and negative ones. So there are two opposite characteristics or features in each are every natural phenomena. Yin is female and Yang is male, the former is passive and the letter is active. Therefore the universe works because of actions and reactions of Yin and Yang (Rainy 2010:137)

According to Imam Ali, the universe is creation of an Ultimate Being (Thaqafi1395AH, V2:731). He is most beneficent, most merciful. He is superior of all things. He might not be understood by finite human minds. No one might understand him however he or she be clever. $\mathrm{He}$ is almighty God. He is all -knowing, all powerful and all seeing as well. (Imam Ali $1395 \mathrm{AH})$.The world has a goal. It is going toward its perfection and predestined way (Motahhari, 1375AH: 55).Imam Ali many times reminded the goal of the Universe in his preaches (JA'fari1377AH:73).

According to Confucius and Imam Ali the universe has an order and goal. The former calls it Tao (Confucius 1359AH: 50) and the latter calls it Tariqah(The Way).

\subsubsection{God}

Imam Ali clearly speaks of God but Confucius has a totally different approach as to this matter. Although he speaks of Heaven or Tian. According to Chinese thought Heaven is superior Bing and greatest God (Groot 1981: 13)

One might come to make similarities among the ideas of the both thinkers. According to them, God and Heaven are origins of ethical sense in men. (Creel 1949: 139)

\subsubsection{Human beings}

According to Confucius(s and Imam Ali, nature of men is good. Confucius holds that nature of men guide them towards good. They both have a positive good act (Yu, 2007, P.56). Imam Ali holds that men are created based on God's nature (Imam Ali 1385AH).The both thinkers have a positive approach toward men's nature. So men's nature, based on their views, is in harmony with the nature. They hold that men should follow their original nature and they should not be deviate from it.

Accordingly both of them hold that men should act in harmony with their innate nature and it is a fixed principal in education and ethical training. According to Imam Ali educational programs should he based on divine nature of men. They envisage men as social beings. They emphasizes on social responsibility of men. Imam Ali emphasizes on man's accompanying with society. He lays stress on social responsibility of men (Imam Ali $1385 \mathrm{AH}$ : 125).He says that men should not isolate himself from his society (Imam Ali 1385AH: 27).Every person, Confucius says, has to be a helper of his society (Creel 1949:50). 
Although both emphasizes on social responsibility of men but they hold that everybody has to keep this or her individuality safe. Therefore one should act both socially and individually.

\subsubsection{The day of resurrection.}

There are big differences among Confucius and Imam Ali in relation to the Day of Judgment. Confucius do not concentrate on other world. He thought this world not the day to come important. Confucius say: while we do not know life well, how could we know death and life after it well (Jaspers 1393: 265).

So Confucius give privilege to the material world while Imam Ali holds nobility for other world. (Imam Ali 1385: 95) It is to be mentioned that Imam Ali's emphasizes on the concept of death. He holds that death has an educational role He says that one had to take his lessons from the death (Imam Ali 1385 AH: 131).

The idea of death reduces man's attachments to the worldly pleasures. But on the other hands, Confucius did not pay to the life after death, reward in the paradise. He put emphasizes on good and rightful acts instead of beliefs of men. (Rainey 1990:201).So he changes the focal point of discussion of death towards the matter of good behavior with died ones. It must be mentioned that Islamic education emphasizes on social benefits and socialism (Shariati 1360AH: 118).So one might find many similarities among Imam Ali and Confucius in regard to importance of society

\subsection{Ethical principles}

\subsubsection{Moderation}

Generally speaking, moderation has been emphasized in many schools of ethics through man's history. Confucius and Imam Ali both encouraged their flowers to moderate with people. That is to say, they hold men should not transgress limits of ethics and not have shortcomings to do their ethical responsibilities.

Ren and Le are two basic elements of Confucius school of ethics .Ren is origin of all men's virtues. It means kindness and merciful before Confucius. But he made it greatest virtue or humanity. Ren means benevolence.

So those who are benevolent in their life they are real human beings. Once he was asked as to the meaning of Ren. He told: "Do not treat men in such a way that you do not like to be treated with you (Confuciuse1955: 76).He came to tell the golden rule of ethics, I.e. "Like for others what you like for yourself" (Yu lan 1380AH, 57)

Imam Ali keeps this benevolence as criteria in social relations. He advises his son: oh my son consider your behavior with people as a standard of conduct. (Imam Ali $1385 \mathrm{AH}$ : 405).That is to say he holds one should act in a way that he or she likes other people behave with him.

Li means proper behavior in each occasion or position (Adler 2002:43).Confucius holds that $\mathrm{Li}$ is an instrument for making balance and harmony in man's feelings. That is to say, it causes moderation in men's behavior. It bans excessiveness (Creel 1949:106).

Li acts as a criteria in bringing up good human relations and it harmonizes social of affairs as well. According to him, Moderation causes kindness and Imam Ali holds that religious orders or Sharia, brings harmony among men's relation with each other. Since they control conducts of human beings. Imam Ali blames ignorant persons since they commit either exceed or make short coming in their behavior (Imam Ali 1385AH:44). Imam Ali has a considerable statement which indicate a humanitarian approach towards men: He says: 
"Behave with people in a good way. Since either they are like you in their creation or they are you brothers in religion (Imam Ali 1385AH: 123)

\subsubsection{Rationality}

The both thinkers have paid much attention to importance of reasoning and thought in their training methods. Both encourage their followers to think and justification. Confucius says "if one learn or memorize orders and laws without understanding them, he or she made waste his or her time (Confucius 1955:90)

Imam Ali says: "there is no benefit in learning without understanding" and in reading without contemplation (Kulayni, 1369 V4:44). Confucius emphasizes on thinking in all events of life. He holds that if one do not accustom to thinking, so he will faces with problems very soon (Yu tang 1943: 50). Imam Ali hold that there is not any worship superior that thinking (Imam Ali 1385AH: 450). They both negate following an idea or person only based on blind imitation.

\subsubsection{Ethical self-improvement or moral refinement}

Confucius encouraged his followers to improve their behavior, purify their souls and make their social relations better. (Creel 1949: 96) According to him the meaning of life is to improve your personality and behavior. It might be important to know that he holds: "The virtue is perfect which adheres to a constant mean." That is to say in a more philosophically phrased translation this becomes: "The use of the moral sentiment, well balanced and kept in perfect equilibrium "(Noss, 1965: 391). Men should try to put aside their selfish wishes and fill themselves with good deeds (legged1879: 27).

Imam Ali holds that men should try to make intimacy to God. This will result to moral refinement. He admonished people: "Supervise your soul" (Imam Ali AH: 359).

Although their motivation in regard to self-refinement and purification of men differed but the results would seem to be similar. That is to say, improvement of men the both thinkers give priority of moral refinement of self for educating other ones. Confucius' aim was to teach his disciples good act and morals. He says if they want to rule so they have to learn to rule on themselves. So the ruler is he who governs himself firstly. One who could not resists against his carnal soul, how would be able to govern others (Confucius 1955: 22).He told that the image of you among people is resulted from your thoughts and acts (Burgan 2008:49)

Imam Ali says: "everybody who wants to teach other persons, he must train himself already (Imam Ali 1385 AH: 450)

It might be interesting that the both thinkers made priority to purify self then doing education of society. The necessary requirement for leadership is to educate one self. A person could train others which already have mode self-purification. One main similarity among these thinkers might be their emphasis might be their emphasis on practical training. As a matter of fact, both of them hold that every moral teacher should teach his disciples practical not orally. Imam Ali says: "Call people towards doing good by your acts not words" (Imam Ali 1385 AH: 440)

\subsubsection{Pragmatism and morality}

The both thinkers pay to practical results of education. Confucius says: the benefit of learning is to realize it (Jaspers1985:239).Imam Ali say: "people when lean good acts, they will practice according them .So they might lead to right way (Kulayni 1369AH V.1: 56) Imam Ali hold that "the calamity of knowledge is not acting according to it (Moayyidi 1393AH:.83) Accordingly if one learn something but do not put it into practice, then it will be useless. 


\subsubsection{Equality of men}

Confucius and Imam Ali considered the matter of equality among people too much. It is said that Confucius was the first teacher who popularize education in China and hold that all people should be educated regardless of their class (Chen 1971:27). He hold that men are basically equal (Creel 1949:51).

Imam Ali was on the view that all men are equal. He wrote to Malik-e Ashtar, one of his companions, as follows: "men are two kinds. They are either your brothers in religiosity or they are human beings tike you". (Imam Ali 1385 AH: 405). When a Leader holds to equality of men in education so it will prepare equal opportunities for all men and vanish all discriminations (Ahmadi 1372 A.H:116)

\subsubsection{The principle of personal difference}

Confucius and Imam Ali had paid attentions to personal differences of their students. Confucius believed that education must be in harmony with personal faculties of educators as well (Fu Chen 1969 Vol.1:177). Confucius usually proposed one question and they gave different answers (Creel, 1949 :99).In fact, he evaluated weakness and strength of every student and then he made advises regarding education according to his capacities.

Imam Ali considered different level of men's understanding them. Even he gave different answers to same questions of his followers based on their different levels of understanding.

\subsubsection{Traditionalism}

Confucius and Imam Ali emphasized on study of history and traditions of last generation. Confucius holds that as a teacher he must interpret old cultural heritage for his students (Yu lan Ibid :40). Confucius came to know past history of china as his main source of his thoughts (Adler Ibid : 40).

Imam Ali considered history as an instrument to educate people. Actually he presented history as a mirror so that people might take lessons from it. Both thinkers put emphasis on experiences of a past generations. Imam Ali told to his son:

"I have studied history of past peoples and last generations so much and so that one may conceive that I have lived with them. Then I could understand useful and harmful things in their history. So I choose useful things of their traditions and put aside harmful one's (Imam Ali 1395: 31)

Both thinkers were on the view that by referring to history and traditions of last generations, men might be able to learn experiences as their future.

\subsubsection{Children and responsibility:}

According to Confucius every child must follow his parents so that he could reach to his ethical perfection. Through following of the parents, one might reach to Ren in Chinese literature and tradition. Confucius believed that to keep respect of parents is among most important virtues. (Adler 2002:87).So he presented filial duty as first step towards moral perfection, (Ming, 2000: 101).

Imam Ali expressed that children should follow their parents in all affairs and do their orders except when they want them to transgress divine orders (Imam Ali 1395AH:.399).Men should accustom to do well towards their parents. It must be mentioned that according to teachings of Islam, Teachers have to pay attention to children' activities. Since knowledge without any practices and acts will be useless (Ibrahim zadeh, 1375AH : 29). 


\section{METHODS OF EDUCATION}

\subsection{Examples and models}

Confucius and Imam Ali hold that human examples have much influence on conduct of men. The rulers, both believed, are among main important examples. Confucius says: the character of a ruler is like a wind and people are similar to vegetables. So vegetables will bend towards the way that wind blow (Ware 1955:.97). They do not concentrate on teaching laws are rules but they mainly stress on personality of rulers, teachers and ethical models and examples.

So they propose idea of "perfect man". It is most praised personality for Confucius. He made efforts to reach men towards this ethical ideal (Hume 1929:100).It is narrated that once Tsze Kung asked: "What constitutes the Superior man? "Confucius replied:" He acts before he speaks and afterwards speaks in accordance with his act (Dawson 1915:62). Accordingly they hold men should act based on ethics and virtues not laws and orders. The former originates from men's wiling and wisdoms but the latter envisage a kind of forceful behavior. Both of the thinkers had influential character and impresses their disciples too much.

Creel holds that Confucius himself was a good example for his followers and it caused causes expansion of his teachings as well (Creel 1971: 115). Confucius emphasizes on li for social solidarity and order but he negate law making in regard to education. In fact, he hold that men should behave based on virtues and morals. (Fu Chen 1969:5). They must not act according to fear of punishment.

Imam Ali's world views include a lot of orders and disorders. Meanwhile it is not imitated to law. So acting based on virtue and piety have an especial place in ideas of Imam Ali. He used to use the method of advising .For example he says to his son: "Make alive your hart with advises (Imam Ali 1395:331).

\subsubsection{Differences among both thinkers:}

Confucius used to use from poems and music for education. That is to say, he put them as a part of his educational program. He hold that music brings concentration and discipline (Bergun 2008: 27). It seems that music could help men to reduces his egocentrism and bring calm for them. By music, he holds, men feel unity with themselves and the universe (Radhakrishnan 1990: 10) He hold that to learn music and to compose poems might bring up thoughts and positive feelings as well.

Imam Ali used to present fluent lectures (Motahhari1375AH:.15). He emphasized on the power of words, their rhythms and style instead of argument and justification.

Confucius had especial audiences. It means that he had a certain circle of disciples (Creel 1971:98). While Imam Ali addressed all people of his time in his sermons and lectures. He made sermons in order to affect people. Imam Ali considered them as instruments to review men's harts (Imam Ali 1395AH:300). While Confucius did not used so much popular sermons.

Confucius and Imam Ali lay stress on common education.

Imam Ali usually addressed all people in his religious lectures directly but Confucius addressed some casts of society. That is to say, Confucius like many other philosophers had especial students. He was busy with his especial students and through their activities he was presented to the world.

\subsubsection{The goals of education:}

Confucius considered aim of education as forming the rule of ethics (Creel 1949:17).His aim was to bring social and worldly welfare for men. According to him, perfect men means a good ruler for the society. So he made efforts to educate disciples who would be respectful, 
pious, moderate brave ones. He had much influences on his society. (Dawson 1915: 35).It would be told that his philosophy must not be evaluated as materialism since he had the idea of revival of ethics and morals in the society. Since his teaching stresses on moral principles (Chen Le 1969: 5)

The main aim of education in Islam is to worship Allah (Shariatmadari 1375AH: 237). Imam Ali's aim of educating was to make intimacy between men and God (Imam Ali 1395:389).So through intimacy to God, man will act as his vicegerent in the earth. So he will reform men's society. The main aim would be to train good ruler for the society. Having a good ruler would help to reform the society.

Both of them viewed social and political power as an instrument. They sought men's salvation while their definition of the concept differed. Both of them wanted to bring out perfect man. According to them the main characteristics of perfect man would be righteous, wise, kind, moderate, right doers and just(Imam Ali 1395:387) and (creed 1971:48).

The differences of the concept of salvation before them would be considered as follow:

Imam Ali's main idea was intimacy of man to God. He wanted to create perfect man and vicegerent of Allah on earth (Motahhari, P.20).Through that Caliph of Allah, i.e. Imam, people will experience both worldly and hereafter welfare as well. Confucius mainly sought worldly welfare of men. So his stress on popular education, perfect men and ethics might be considered as his instruments to reach to his purposes (Creel 1949:7). Confucius hold that awe must reform society through educating the rulers (Adler,2002, P.20).

\section{CONCLUSION}

The study of works and ideas of Confucius, a social philosopher of China and Imam Ali, a prominent religious leader of Shiite Islam, on education indicates that both of them had attention to it. One might conclude that although they belong to two different traditions but there are similarities among them as to teachings and education. Both have an idealistic worldview. They hold it is too important for men. They considered man in need to education too much. According to the both thinkers, the education has a vital effect in man's personal and social life. They hold to God or supernatural realities .They emphasis on moderation, rationality, ethical self-improvement or moral refinement, pragmatism and morality, equality of men, the principle of personal difference, traditionalism, children and responsibility, methods of Education. Of course there are naturally some differences among Confucius the philosopher and Imam Ali. 


\section{REFERENCES}

Adler, Joseph, 2002, Chinese Religions, Routledge. A Persian translation by Hasan afshar ,Markaz ,Tehran

Ahmadi, Ahmad, 1372AH, Usul va Raveshhaye Tarbiyyat dar Islam, Jihad Daneshgahi, Tehran.

Burgan, Michael, 2008, Confucius: Chinese Philosopher and Teacher, Compass Point Books.

Chen Li - Fu, 1986, Confucian Way, the Story of Chinese Philosophy, Routledge,

Creed, Herrlee, Glessner, 1380AH, Chinese Thought, from Confucius to Mao Tse-tung, University of Chicago Press, The Persian translation,Giti Vaziri,Sorosh ,Tehran

Creel, H. J, 1949, Confucius and the Chinese Way, Harper.

Dawson, Miles Menander, 1915, The Ethics of Confucius, G.P .Pullman's Sons, New York and London.

Groot, j, 1981, Confucian Religion, in Encyclopedia of Religion and Ethics, ed. James Hestings, Vol.4 , T \&T Clark, Edinburgh,

Hosayini Sardari, Ali Akbar,1364AH, Mabahei Chand piramoone Mabanii Talim va Tarbiyyat Islami,Nashre Farhang Islami,Tehran

Hume, Robert, Ernest, 1929The World's Living Religions, T. \& Clark Ltd.

Imam Ali,1385 AH , Nahj al Balagheh,Astan e Qods Publication ,Tehran,

Ja'fari,Mohammad Taqi,1377,Insan Dar Islam,nashre Farhang e Islami,Tehran

Jaspers, Karl, 1393, Socrates, Buddha, Confucius and Jesus, Harcourt, Brace, Jovanovich.The Persian translation by Asadullah Mobasheeri,Niloofar,Tehran

Kulayni, Mohammad bin Yaqub, 1369 AH, Usul e Kafi, Persian Translation, Entisharat e Islamiyyah, Tehran.

Legged, James, The Sacred Books of China, , Editor ,Friedrich Max Muller, Original Texts of Confucianism , Oxford ,Clarendon Press , 1879

Ming, Do Vi, 2000, Confucius \& Confuciunism, in Encyclopaedia Britanica.

Modarresi,Mohammad Taqi,1380AH,Zendeginameh e Chahardah Masum,Persian translation by Mohammad Sadeq Shariat,Mohebban al Husain,Tehran

Moayyedi ,Morteza ,1393AH, Bab- al Elm, Ashiyaneh Bartar,Isfahan

Motahhari,Morteza ,1375AH,Sairi Dar Nahj Al Balaghah ,Sadra,Tehran

Motahhari,Morteza ,1378, AH, Insan e Kamel , Sadra ,Tehran.

Noss, John B, 1965, Man's Religions, the Macmillan Company New York.

Qomi , Abbas , Safinah Al-Behar, 1426,Astan - qods e razavi ,Mashhad

Radhakrishnan, S, Sarvepalli, 1990, History of Philosophy Eastern and Western. George Allen \& Unwin.

Rainy, lee Dian, 2010, Confucius and Confucianism, The Essentials, Willy, Black well, New Jercy.

Rainy, lee, Dian, 1990, life after Death, Some early Confucian Views, UMI Diss. Service. 
Seminare Talim va Tarbiyyat dar Sokhanan va Sireh e Imam Ali, Tehran, Ministry of Education, $378 \mathrm{AH}$

Shahidi, Jaafar,1384AH, Zendegi Amir e Momenan Ali, Nashre Farhang e Islami, Tehran

Shariati,Ali ,Falsafeh Talim va Tarbiyat,Tehran,Besat,1347AH

Shariatmadari, Ali, 1360 AH , Usul va Falsafeh Talim va Tarbiyyat, Elm ,Tehran,

Tabresi,amin al Islam,1398AH , Zendeginameh e Chahardah Masum,A Translation of A'lam al Vara be A'lam Al Hoda,Aziz ullah atarodi,Islamiyyah,Tehran

ThaqafiIbrahim Ibn Mohammad Ibn Said Ibn Alhelal,1395AH,Algharat Ave Alistinfarat, 2 Volume Anjoman e Asar e Melli,tehran

Yu - Lan Fung,1380AH , A History of Chinese Philosophy, Princeton University Press,A translation into Persian by Farideh Javaher kalam,Farzan.Tehran

Yu tang, Lin, 1943, The Wisdom of Confucius, Random House.

Ware ,James , R,1955, The Sayings of Confucius, the New American Library ,New York

Walshe,W.Gilbert , 1981 , "Confucius" in Encyclopaedia of Religion and Ethics, James Hastings, T\&Tclark,Edinburgh,vol 3 